\title{
Fenomena Kecanduan Penggunaan Gawai (Gadget) pada Kalangan Remaja Suku Bajo
}

\author{
Chaidirman $^{1}$, Diah Indriastuti ${ }^{1}$, Narmi $^{1}$ \\ ${ }^{1}$ STIKes Karya Kesehatan, Kendari, Indonesia \\ nsdiahindri@gmail.com
}

\begin{abstract}
Background: Socially the use of devices causes teenagers to become less sociable. Many teenagers spend most of their time playing gadgets so they carry them wherever they go. This happens to the Bajo tribes who experience social changes that have an impact on their life patterns.
\end{abstract}

Method: This study was a qualitative study with a phenomenological approach with the population in this study were the teenagers of the Bajo Tribe in Wakatobi Regency as many as 227 people and the number of samples was six adolescences Bajo Tribe. Using samples with a purposive sampling technique. For gathering the data, the investigator employed interview and observation guidelines, video recorder, and field note. The researchers used observation, interview and video recording in collecting the data and employed thematic analysis in data analysis.

Results: The results of the research on these were three themes including namely the use of devices, addiction and socialization revealed that the use of devices requires costs for operations and excessive use of devices will have an impact on health where adolescents have a sense of dependence on devices that have attractive designs, and cause individual and indifferent attitudes.

Discussion: The conclusion of this study is that adolescents begin to lose time for socializing due to the use of devices that are interested in the applications in it.

Keywords: Addictions, Bajo Tribe, Gadget, Teenagers.

\begin{abstract}
Abstrak
Pendahuluan: Penggunaan gawai menyebabkan remaja menjadi kurang bersosialisasi menghabiskan sebagian besar waktu dengan memainkan gawai dan membawa gawai kemanapun pergi. Hal tersebut terjadi pada Suku Bajo yang mengalami perubahan sosial sehingga berdampak pada pola kehidupan.

Metode: Penelitian ini adalah penelitian kualitatif dengan pendekatan fenomenologi dengan populasi dalam penelitian ini adalah remaja Suku Bajo sebanyak 227 orang dan jumlah sampel sebanyak enam remaja remaja Suku Bajo yang kecanduan dengan teknik purposive sampling. Alat bantu pengambilan data yang digunakan meliputi panduan wawancara, video recorder, lembar observasi dan field note. Metode pengambilan meliputi observasi, wawancara, dan dokumentasi. Analisis data menggunakan analisis tematik.
\end{abstract}


Hasil: Hasil penelitian tiga tema ini yaitu pemakaian gawai, kecanduan dan sosialisasi mengungkapkan bahwa pemakaian gawai memerlukan biaya untuk operasional dan pemakaian gawai secara berlebihan akan berdampak bagi kesehatan dimana remaja memiliki rasa ketergantungan terhadap gawai yang memiliki desain menarik, serta menimbulkan sikap individual dan acuh tak acuh.

Kesimpulan: Simpulan penelitian ini adalah remaja mulai kehilangan waktu bersosialisasi akibat penggunaan gawai yang tertarik pada aplikasi yang ada di dalamnya.

Kata kunci : Gawai, Kecanduan, Remaja, Suku Bajo.

\section{PENDAHULUAN}

Gawai pada mulanya diciptakan untuk mempermudah komunikasi, namun seiring perkembangan zaman memiliki tambahan fitur yang memudahkan kehidupan namun juga meiliki dampak negatif termasuk yang terjadi di Indonesia (Admar, Yakub, \& Rosmawati, 2018; Al Ayouby, 2017). Efek pancaran radiasi diyakini dapat mempengatuhi kesehatan seperti penurunan fungsi penglihatan dan pendengaran serta perubahan pola tidur yang cenderung terganggu (Tarigan, 2018; Waty \& Fourianalistyawati, 2018).

Gawai juga menyebabkan gangguan sosial seperti gangguan interaksi sosial dengan lingkungan dan berkurangnya kegiatan fisik akibat kecanduan gawai (Tarigan, 2018). Perilaku tersebut tidak lepas dari fase peralihan dari masa remaja (Darnoto, 2016). Kesibukan remaja diisi dengan gawai karena tidak ingin disebut sebagai orang gagap teknologi sehingga membawa gawai kemanapun pergi (Mawitjere, Onibala, \& Ismanto, 2017).

Associated Chamber of Commerce and Industry of India melakukan penelitian dengan sampel remaja di India dengan hasil menyatakan bahwa durasi waktu penggunaan gawai telah mempengaruhi kualitas kesehatan mereka seperti kesulitan tidur dan sosialisasi pribadi yang kurang baik (Mawitjere et al., 2017). Penelitian terdahulu mengungkapkan alasan pengguna gawai menjadi cemas adalah saat jaringan tidak terjangkau, tenaga gawai habis dan hilangnya gawai (Hafni, 2018). Data pada tahun 2013 di dunia 7,2\% anak berusia 5-19 telah terdiagnosa Gangguan Pemusatan Perhatian Hiperaktifitas (GPPH), di Indonesia tahun 2015 dijumpai sekitar 9,2\% laki-laki dan $2,9 \%$ perempuan mengalami GPPH (Setianingsih, Ardani, \& Khayati, 2018).

Pengguna gawai pada tahun 2013 dengan $27 \%$ populasi dunia mencapai 1,9 miliar dan diprediksi jumlah pengguna gawai akan terus meningkat sampai 5,6 milyar pada tahun 2019 (Pandey, Ratag, \& Langi, 2019). Di Asia Tenggara pada bulan Agustus 2014 pengguna gawai sebanyak 120 juta yang telah mengalami peningkatan sebanyak $44 \%$ setiap tahunnya, sedangkan dari data penjualan gawai di Indonesia tahun 2014 dengan pengguna aktif mencapai sebanyak 47 juta jiwa pengguna (Riani, 2016). Pecandu gawai pada tahun 2014 di Indonesia semakin meningkat dari 1,4 miliar 
pengguna gawai 176 juta orang diantaranya adalah pecandu gawai, angka ini meningkat $123 \%$ dibanding tahun 2013 yang hanya 79 juta orang (Purwanto, Atina, \& Desylawati, 2017). Pengguna aplikasi game online melalui gawai dan telah mengalami ketergantungan gawai di Indonesia tahun 2017 terindikasi sejumlah 6 juta dengan pengguna remaja kurang lebih 40\% (Sari \& Prajayanti, 2017).

Kewaspadaan terbahadap perilaku kecanduan gawai harus ditingkatkan karena dapat menurunkan kualitas sehat dan kehidupan sosial remaja (Mawitjere $e t$ al., 2017; Tarigan, 2018). Gangguan kesehatan akibat penggunaan gawai pada pecandu game online diantaranya gangguan pada mata, gangguan tidur dan saraf sehingga sering pusing (Sari \& Prajayanti, 2017). Perubahan sosial masyarakat yang terjadi diantaranya pergeseran pola hidup ditandai dengan hilangnya jiwa sosial, penghormatan antar sesama menjadi masyarakat yang abai serta individual yang rawan konflik (Suryanegara, Suprajaka, \& Nahib, 2015). Hal tersebut berlaku juga pada remaja Suku Bajo (Bajau) yang mengalami perubahan sosial dipengaruhi oleh pola hidup konsumtif seperti (kendaraan pribadi, parabola, gawai, dan lain sebagainya) (Suryanegara et al., 2015). Suku Bajo (Bajau) adalah bangsa pengembara lautan luas atau biasa disebut sea nomads, dimana secara pendidikan cenderung tertinggal karena kehidupannya dihabiskan di tengah laut (Alauddin, Bauto, \& Sarpin, 2016). Penelitian sebelumnya tentang gawai menunjukkan adanya hubungan dan pengaruh yang signifikan mengenai penggunaan gawai pada kesehatan (Dalillah, 2019; Darnoto, 2016; Mawitjere et al., 2017; Pandey et al., 2019; Pangastuti, 2017; Sari \& Prajayanti, 2017; Setianingsih et al., 2018; Suryanegara et al., 2015). Perbedaan pada penelitian ini adalah populasi yang dijadikan sasaran yaitu Suku Bajo yang terkenal sebagai suku yang hidup jauh dari gaya hidup masyarakat daratan. Tujuan penelitian ini adalah untuk menguraikan fenomena kecanduan penggunaan gawai pada kalangan remaja Suku Bajo di sebuah desa di Kabupaten Wakatobi

\section{METODE}

Desain penelitian yang digunakan dalam penelitian ini adalah kualitatif dengan pendekatan fenomenologi (Saryono \& Anggreani, 2017). Penelitian ini dilakukan pada tanggal 13-22 Juli 2019. Populasi dalam penelitian ini adalah remaja Suku Bajo di Kabupaten Wakatobi sebanyak 227 orang dan jumlah sampel sebanyak enam orang menggunakan sampel dengan teknik purposive sampling, Kriteria yang telah ditentukan yaitu remaja yang kecanduan gawai di Suku Bajo. Alat bantu pengambilan data yang digunakan meliputi panduan wawancara, video recorder, lembar observasi dan field note. Pengumpulan data kualitatif meliputi observasi, wawancara, dan dokumentasi. Penelitian ini memiliki ethical clearance dari Komisi Etik Penelitian Kesehatan PENGDA IAKMI SULTRA dengan nomor 005/KEPK/IAKMI/VI/2019. 


\section{HASIL}

\section{Gambaran Penggunaan Gawai pada Kalangan Remaja di Suku Bajo Kabupaten Wakatobi}

Tema pemakaian gawai digambarkan melalui tiga kategori yaitu "biaya membeli paket data", "cara membeli paket data", dan "cara lain mengakses internet di gawai".

Kategori "biaya membeli paket data"s diidentikkan dengan kata kunci "40 ribu", "82 ribu", "tidak menentu", "105 ribu", "53 ribu", dan "38 ribu" sebagai berikut:

“..itupun paling beli data nda banyak yah sekitar 40 ribu untuk 1 bulan...”(P1)

“..kalau saya biasanya beli paket lumayan mahal ada ada sampai 82 ribu ...."(

“...biaya beli paket tidak menentu..."(P3)

“...untuk beli paket yah harganya lumayan sekitar 105 ribu ..."(P4)

“...saya beli yang harganya kadang sampai 53 ribu..."(P5)

“...untuk beli paket yang biasanya saya beli yang harga 38 ribu ..." (P6)

"...tiap-tiap orang tidak menentu harganya untuk membeli paket data..."(PT1)

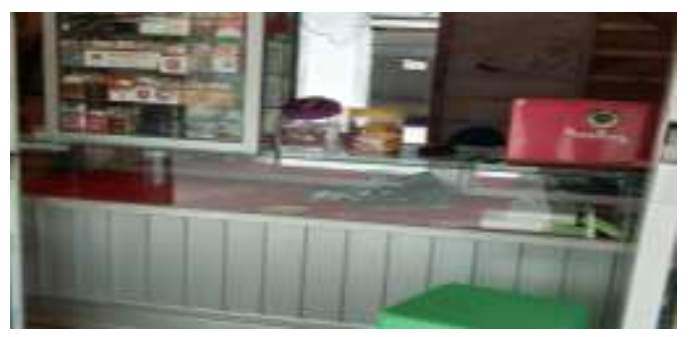

Gambar 1. Kios Penjual Pulsa

Peneliti menemukan adanya kios yang menyediakan pembelian paket data dan pulsa.

Kategori "cara membeli paket data" diidentikkan dengan kata kunci "bekerja" dan "orang tua" sebagai berikut: “...bekerja jadi nelayan untuk beli itu data..."(P1)

“...kadang orang tua, kadang dari kerja juga..."(P2)

“...uang dari orang tua...”(P3)

“...dari uang orang tua...”(P4)

“...dikasih orang tua...”(P5)

“...dari hasil bekerja saya kumpulkumpul..."(P6)

“...kebanyakan mereka bekerja sebagai nelayan jadi uangnya mereka bisa pakai membeli paket data... "(PT1)

Kategori "cara lain mengakses internet di gawai" diidentikkan dengan kata kunci "Wi-Fi" dan "tethering" sebagai berikut:

" ...saya pakai Wi-Fi kalau mau pake kuota pasti makan banyak..."(P1)

"...kita mabar pakai Wi-Fi di kantor desa jadi tidak khwatir habis paket ..."(P2)

“...pake jaringan Wi-Fi ...”(P3)

“...kadang juga saya tethering sama teman ..."(P4)

“...kadang tethering, kadang pakai wifi dikator desa..."(P5)

“...saya pake Wi-Fi juga tapi kadang thetring..."(P6)

"...mereka pakai Wi-Fi di kantor desa...”(PT1)

\section{Gambaran Kecanduan Penggunaan Gawai pada Kalangan Remaja Suku Bajo Kabupaten Wakatobi}

Tema "kecanduan" melalui empat kategori yaitu durasi penggunaan gawai, aplikasi yang paling disukai, waktu dan masalah yang dialami. Kategori durasi penggunaan gawai diidentikkan dengan kata kunci 12 jam, 10-12 jam, 8 jam, 5-8 jam, dan 10 jam sebagai berikut:

"...kira-kira saya bermain hampir 12 jam..."(P1)

“....kira-kira 10-12 jam...”(P2)

“...kalau main hp ada mungkin 8 jam... ”(P3)

“....saya kira-kira sekitar 8 jam...” (P4)

“...ada sekitar 5-8 jam ...”(P5) 
“...saya kira-kira sampai 10 jam lamanya saya pake $h p . .$. (P6)

" ...biasanya mereka main HP dari sore sampai tengah malam, sekitar 5-10 jam... “(PT1)

Kategori "aplikasi yang paling disukai" diidentikkan dengan kata kunci "whatsapp", "facebook" dan "game online" sebagai berikut :

“.... Game online kaya pubg begitu, saya suka main..." (P1)

“....game online kita suka mabar di kantor desa sampai tengah malam..."(P2)

“...biasanya buka-buka whatsapp dengan facebook ..."(P3)

“...main HP buka aplikasi whatsapp untuk chat..." (P4)

“... suka main game online free fire sama pubg mabar sama teman-teman sampai tengah malam..."(P5)

“....game online sama teman-teman karna suka main bersama-sama di kantor

desa..."(P6)

“...biasanya mereka datang main di kantor desa..." (PT1)

Kategori "waktu" diidentikkan dengan kata kunci "pagi", "siang", "sore" dan "malam" sebagai berikut:

“...biasanya saya ke kantor desa dari sore sampai tengah malam ..."(P1)

“...saya biasanya main malam saja”( $\mathbf{P 2})$

“...kadang pagi sampai malam...”( P3)

“...Pas pulang sekolah dari sore sampai malam..." (P4)

“...main hp biasaya malam saja...”(

“... sore sampai malam...”(P6)

“...biasanya mereka datang main dari sore sampai malam....”(PT1)

Kategori "masalah yang dialami selama memakai gawai" diidentikkan dengan kata kunci "tidak ada", "mengantuk saat di sekolah" dan "bangun kesiangan" sebagai berikut:

"...selama ini tidak ada keluhan apapun...”(P1) "...terlalu lama main HP jadi kurang fokus saat bekerja...”(P2)

“...saya suka bangun kesiangan...”(P3)

“...mengantuk saat di sekolah karena habis bergadang..."(P4)

"...kadang bagun kesiangan dan mengantuk saat di sekolah nongkrong sama teman-teman..."(P5)

“...tidak ada masalah apa-apa...”(P6)

“...untuk saat ini tidak ada saya dengar keluhan terkait dengan pemakaian HP ..."(PT1)

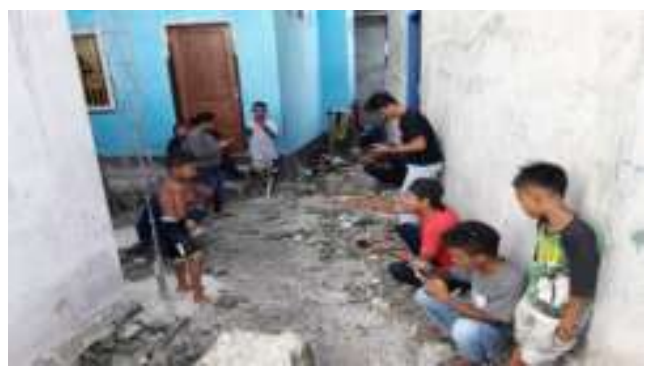

Gambar 2. Kondisi posisi saat bermain gawai

Peneliti mendapatkan remaja dalam keadaan posisi yang tidak ergonomis, seperti jongkok, berdiri dan bersandar di dinding .

\section{Bentuk Perubahan Sosial pada Kalangan Remaja Suku Bajo di Kabupaten Wakatobi}

Tema sosialisasi terbagi melalui dua kategori yaitu "kelompok" dan "tempat".

Kategori "kelompok" diidentikkan dengan kata kunci "sendiri" dan "sama teman-teman" sebagai berikut:

“...sendiri, kadang sama teman-teman... “(P1)

“.....sambil mabar dengan teman...”(P2)

“...kalau di ajak ya sama teman-teman..." (P3)

"...biasanya main hp sama teman-teman tapi kadang sendiri..."(P4) 
“...dikantor desa juga sama teman-teman saja..."(P5)

“...kalau main hp sama temanteman..."(P6)

“...biasanya mereka duduk-duduk disini sama teman-temanya..."(PT1)

Kategori "tempat" diidentikkan dengan kata kunci "di kantor desa", "di kamar", "di rumah" dan "di rumah teman" sebagai berikut :

“...di belakang kantor desa karna ada wifi..."(P1)

“...di kantor desa main HP sambil mabar..."(P2)

“...main HP di rumah, kadang di kantor desa..."(P3)

“...malas keluar rumah jadi di kamar dengan disini dikantor desa..."(P4)

“...di rumah teman kadang di kantor desa....."(P5)

“...di kamar biasanya sering di kantor desa..."(P6)

"...sering sekali mereka main HP di kantor desa karena pakai wifi..."(PT1)

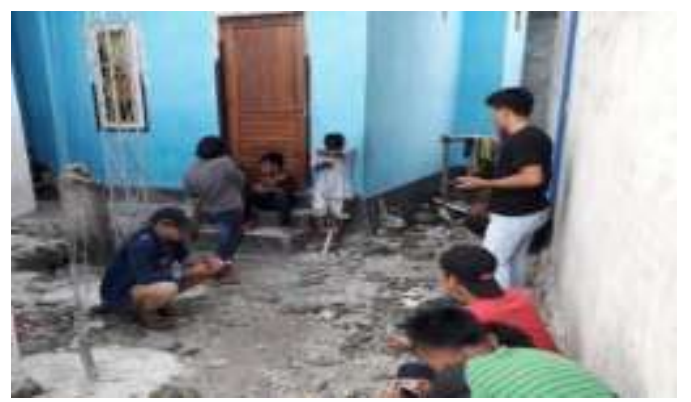

Gambar 3. kondisi lokasi bermain gawai

Peneliti menemukan remaja pada saat memainkan gawai dengan memanfaatkan wifi tidak terdapat fasilitas seperti meja dan kursi.

\section{PEMBAHASAN}

Gambaran Penggunaan Gawai pada Kalangan Remaja di Suku Bajo Kabupaten Wakatobi
Partisipan membeli paket data 38-105 ribu, dari biaya hasil bekerja dan diberi orang tua, selain membeli paket data partisipan mangakses internet dengan memanfaatkan wifi. Wi-Fi atau kependekan dari Wireless Fidelity merupakan sebuah teknologi yang memungkinkan penggunanya melakukan akses pada internet tanpa menggunakan kabel (Mukarim, 2014).

Temuan hasil penelitian yang didapatkan Dalillah bahwa penggunaan gawai memerlukan biaya operasional untuk komunikasi contonya membeli pulsa, biaya servis dan pembelian aksesoris, hal ini menyebabkan pemborosan biaya gawai yang tidak akan ada habisnya (Dalillah, 2019). Penelitian sebelumnya yang telah dilakukan oleh Aziz memperkuat hasil penelitian ini bahwa hampir seluruh remaja tertarik memakai gawai karena teknologi dengan berbagai fitur sehingga pengguna gawai dapat mengakses apapun lewat gawai (Aziz, 2016).

Penelitian menemukan bahwa partisipan dalam menggunakan gawai banyak menghabiskan sebagian besar biaya pembeli paket data dan memanfaatkan fasilitas $\mathrm{Wi}-\mathrm{Fi}$ yang ada guna mendapatkan akses internet untuk mengguakan aplikasi yang mainkanya

\section{Gambaran Kecanduan Penggunaan Gawai pada Kalangan Remaja Suku Bajo Kabupaten Wakatobi}

Partisipan memakai gawai 5-12 jam dan terdapat dua partisipan yang masalah seperti mengantuk dan bangun kesiangan, aplikasi yang paling disukai adalah game online.

Hasil penelitian ini menunjukkan bahwa remaja telah mengalami kelebihan screen time yaitu penggunaan gawai kurang lebih selama 6-8 jam atau lebih setiap harinya (Tarigan, 2018). Hal tersebut menyebabkan gangguan pola tidur karena mudah dioperasikan tanpa melihat tempat dan waktu, dorongan rasa ingin tahu pada perubahan teknologi, kemudahan untuk mengakses informasi melalui telepon pintar penggunaan gawai dan tidak mudah untuk melepaskan gawai sehingga menyebabkan kecanduan terhadap gawai (Waty \& Fourianalistyawati, 2018). 
Penelitian terdahulu menjelaskan bahwa perilaku pemakain gawai dalam waktu lama patut di waspadai karena dapat menggangu kesehatan dan kehidupan sosial remaja seperti gangguan saraf, mata, telinga, kecanduan, egois, tidak peka terhadap lingkungan dan gangguan pola tidur (Mawitjere et al., 2017; Pangastuti, 2017; Sari \& Prajayanti, 2017). Hasil penelitian menujukkan bahwa dalam penggunaan gawai yang berlebihan dapat menimbulkan dampak bagi kesehatan yaitu terjadi gangguan pola tidur dan kurang peka terhadap lingkungan sekitar yang bersikap individual.

\section{Bentuk Perubahan Sosial pada Kalangan Remaja Suku Bajo di Kabupaten Wakatobi}

Penelitian ini menunjukan bahwa remaja mengalami proses isolasi sosial dimana lingkup pergaulannya menyempit hanya dengan teman sesama pengguna gawai bahkan sendirian, lokasi tempat bergaul terbatas hanya disekitar kantor desa. Penelitian ini menunjukkan bahwa pada umumnya partisipan ditemani oleh teman-teman dalam memakai gawai dan di kantor desa sebagai tempat partisipan dalam memakai gawai.

Isolasi yang mulai terjadi pada remaja suku bajo merupakan bentuk pengalaman seseorang yang menjauh dari orang lain disertai perasaan sungkan pada orang lain dengan pemahaman yang kurang menyenangkan (Suerni \& Ph, 2019). Perubahan sosial budaya Suku Bajo dapat dilihat dari aktivitas hidupnya di perahu kayu diatas air selama berabad-abad yang mulai berkurang dengan adanya perubahan sosial dan budaya (Suryanegara et al., 2015).

Penelitian sebelumnya menunjukkan bahwa terjadi perubahan pola hidup maritim tradisional akibat terpengaruh oleh modernisasi masyarakat daratan sehingga terjadi perubahan sosial yang dipengaruhi oleh pola hidup konsumtif seperti memiliki kendaraan pribadi, parabola, gawai, individual, abai dan lain sebagainya (Aziz, 2016; Suryanegara et al., 2015). Hasil penelitian ini menunjukkan bahwa remaja mengalami kecanduan gawai kemudian terjadi buruknya komunikasi remaja terhadap sekitarnya yang menyebabkan menurunnya interaksi sosial dengan lingkungan, selain itu remaja menjadi kurang sehat akibat gerakan dan posisi yang monoton akibar aktivitas dengan gawainya.

\section{KESIMPULAN DAN SARAN}

Penggunaan gawai membutuhkan biaya yang untuk dapat mengoperasionalkan gawai sehingga terjadi pemborosan biaya karena remaja memiliki rasa ketergantungan terhadap gawai dan berusaha untuk selalu memfungsikan gawainya dalam posisi online. Penggunaan gawai secara berlebihan menyebabkan para remaja kurang bersosialisasi karena hanya berinteraksi dengan orang sekitarnya sesama pengguna gawai dan aktivitas fisik menurun sebab kurang banyak bergerak dan mengalami dampak gangguan kesehatan.

Saran bagi peneliti kepada Pemerintah Desa agar melakukan sosialisasi rutin tentang bahaya kecanduan penggunaan gawai bagi masyarakat khususnya para remaja yang masih membutuhkan edukasi untuk mengurangi penggunaan gawai yang berlebihan dan pada masyarakat, untuk menimbulkan kesadaran mengenai dampak kecanduan penggunaan gawai

\section{DAFTAR PUSTAKA}

Admar, H., Yakub, E., \& Rosmawati. (2018). Penggunaan gadget dan kepribadian penggunanya di SMPN 3 Pekanbaru. Jom Fkip, 5(2), 1-12.

Alauddin, I. M., Bauto, M. L. O., \& Sarpin. (2016). Perubahan pola kehidupan Suku Bajo pasca penetapan zonasi taman nasional: Studi di Desa Lamanggau Kecamatan Tomia 
Kabupaten Wakatobi. Jurnal Neo Societal, 1(1), 23-33.

Al Ayouby, M. H. (2017). Dampak penggunaan gadget pada anak usia dini: Studi di PAUD dan TK Handayani Bandar Lampung. Universitas Lampung.

Aziz, A. (2016). Handphone mempengaruhi terhadap perilaku remaja usia SLTP (13-15 Tahun) di Dusun Tegalpare Kecamatan Muncar Kabupaten Banyuwangi. Jurnal Darussalam: Jurnal Pendidikan, Komunikasi dan Pemikiran Hukum Islam, VII(2), 352-377.

Dalillah. (2019). Pengaruh penggunaan gadget terhadap perilaku sosial siswa di SMA Darussalam Ciputat. Universitas Islam Negeri Syarif Hidayatullah.

Darnoto, A. R. P. (2016). Hubungan penggunaan smartphone dengan perilaku seksual remaja di SMAN " $X$ ” Jember. Universitas Jember.

Hafni, N. D. (2018). Nomophobhia, penyakit masyarakat modern. AlHikmah, 6(2), 41-50.

Mawitjere, O. T., Onibala, F., \& Ismanto, Y. A. (2017). Hubungan lama penggunaan gadget dengan kejadian insomnia pada siswa siswi di SMA Negeri 1 Kawangkoan. E-Journal Keperawatan, 5(1), 1-5.

Mukarim, Y. (2014). Monitoring pengaksesan layanan Wifi di Universitas Muhammadiyah Surakarta. Universitas Muhammadyah Surakarta.

Pandey, C. M., Ratag, B. T., \& Langi, F. L. F. (2019). Hubungan antara kecanduan smartphone dengan kualitas tidur pada siswa SMA Negeri 1 Maesaan Kabupaten Minahasa Selatan. Jurnal Kesmas, 8(2), 22-29.

Pangastuti, R. (2017). Fenomena gadget dan perkembangan sosial bagi anak usia dini. Indonesia Journal of Islamic Early Chlidhood Education, 2(2), 166-174.

Purwanto, E., Atina, V., \& Desylawati, E. S. (2017). Sistem pakar deteksi dini gangguan mata dan syaraf akibat penggunaan smartphone. Jurnal Informatika Upgris, 3(2), 152-162.

Riani, V. F. (2016). Gambaran ketergantungan smartphone terhadap produktivitas kerja pada pekerja $C V$. Traveline Citra Nusantara Yogyakarta. Sanata Dharma Yogyakarta.

Sari, I. M., \& Prajayanti, E. D. (2017). Peningkatan pengetahuan siswa SMP tentang dampak negatif game online bagi kesehatan. Gemassika, 1(2), 3139.

Saryono, \& Anggreani, M. D. (2017). Metodologi penelitian kualitatif dan kuantitatif dalam bidang kesehatan (H. Isna, Ed.). Yogyakarta: Nuha Medika.

Setianingsih, Ardani, A. W., \& Khayati, F. N. (2018). Dampak penggunaan gadget pada anak usia prasekolah dapat meningkatkan resiko gangguan pemusatan perhatian dan hiperaktivitas. Gaster, XVI(2), 191205.

Suerni, T., \& Ph, L. (2019). Gambaran faktor predisposisi pasien isolasi sosial. Jurnal Keperawatan, 11(1), 57-66. 
Suryanegara, E., Suprajaka, \& Nahib, I.

(2015). Perubahan sosial pada kehidupan Suku Bajo: studi kasus di Kepulauan Wakatobi, Sulawesi Tenggara [Social Change on Bajo Tribe: Case Study in Wakatobi Islands, Southeast Sulawesi]. Globe, 17(1), 67-78.

Tarigan, M. B. (2018). Hubungan gaya hidup remaja terhadap kejadian anemia pada remaja putri kelas $X$ di SMAN 2 Binjai Tahun 2018. Jurnal Mutiara Pendidikan Indonesia, 4(1), 20-28.

Waty, L. P., \& Fourianalistyawati, E. (2018). Dinamika kecanduan telepon Pintar (Smartphone) pada remaja dan trait mindfulness sebagai alternatif solusi. Jurnal Psikologi Unsyiah, 1(2), 84-101 